\title{
Bacterially expressed truncated F2 domain of Plasmodium falciparum EBA-140 antigen can bind to human erythrocytes*
}

\author{
Joanna Rydzak1, Katarzyna Kryńska1, Anna Suchanowska1, Radosław Kaczmarek1, \\ Jolanta Łukasiewicz'1, Marcin Czerwiński and Ewa Jaśkiewicz'1,2,凶
}

'Ludwik Hirszfeld Institute of Immunology and Experimental Therapy, Polish Academy of Sciences, Wrocław, Poland; ${ }^{2}$ Department of Molecular Biology, University of Zielona Góra, Zielona Góra, Poland

The recently identified erythrocyte binding antigen-140 (EBA-140) is a member of the Plasmodium falciparum DBL family of erythrocyte binding proteins, which are considered as prospective candidates for malaria vaccine development. The EBA-140 ligand is a paralogue of the well-characterized $P$. falciparum EBA-175 antigen. They share homology of domain structure, including Region II, which consists of two homologous F1 and F2 domains and is responsible for ligand-erythrocyte interaction during invasion. It was shown that the F2 domain of EBA175 antigen seems to be more important for erythrocyte binding. In order to study activity and immunogenicity of EBA-140 antigen F2 domain, it is necessary to obtain recombinant protein of high purity and in a sufficient amount, which used to pose a challenge due to the high content of disulphide bridges. Here, we present a new method for expression and purification of Plasmodium falciparum EBA-140 antigen F2 domain in E. coli Rosettagami strain in fusion with the maltose binding protein (MBP). The truncated F2 domain formed by spontaneous proteolytic degradation of the fusion protein was purified by affinity chromatography on Ni-NTA resin followed by size exclusion chromatography. Molecular mass of this protein was confirmed by mass spectrometry. Its $\mathrm{N}$-terminal amino acid sequencing revealed a proteolytic cleavage site within the F2 domain. The proper folding of the recombinant, truncated F2 domain of EBA140 antigen was confirmed by circular dichroism analysis. The truncated F2 domain can specifically bind to human erythrocytes but its binding is not as efficient as that of full Region II. This confirms that both the F1 and F2 domains of EBA-140 antigen are required for effective erythrocyte binding.

Key words: Plasmodium falciparum, EBA-140 antigen, recombinant F2 domain expression, truncated F2 domain purification, human erythrocyte binding

Received: 30 October, 2012; revised: 25 November, 2012; accepted: 05 December, 2012; available on-line: 11 December, 2012

\section{INTRODUCTION}

Malaria is caused in humans by five species of Plasmodium: $P$. vivax, $P$. ovale, $P$. malariae, $P$. knowlesi and $P$. falciparum. Although P. vivax is most widely spread, $P$. falciparum is responsible for the greatest number of deaths (Greenwood et al., 2008; Pierce \& Miller, 2009). Erythrocyte invasion by the blood-stage malaria parasites is a multistep process involving specific interactions between ligands of merozoites and receptors on the red blood cells (Gaur et al., 2004; Cowman \& Crabb, 2006; Jaśkiewicz et al., 2010). Two protein families play central roles in this process: the Duffy binding-like (DBL) and the reticulocyte binding-like (RBL) proteins. In $P$. falciparum there are several members of the DBL family, including erythrocyte binding-like (EBL) proteins, which enable the parasite to interact with independent receptors and define alternative invasion pathways. Four functional $P$. falciparum EBL proteins have been characterized: erythrocyte binding antigen-175 (EBA-175), EBA-140 (also known as BAEBL), EBA-181 (also known as JESEBL) and erythrocyte binding ligand-1 (EBL-1) (Cowman \& Crabb, 2006). All these proteins contain several conserved regions, including Region II, which is involved in receptor binding and consists of two cysteine-rich domains: F1 and F2. EBA-175 is a well-studied P. falciparum merozoite ligand that binds to glycophorin A (GPA) on human erythrocytes (Sim et al. 1994; Pandley et al., 2002; Tolia et al. 2005; Jaśkiewicz, 2007). The recently identified EBA-140 homologous ligand binds to glycophorin C (GPC), a minor erythrocyte sialoglycoprotein (Jaśkiewicz, 1991), and mediates a distinct invasion pathway of human erythrocytes (Thompson et al., 2001; Narum et al., 2002; Gilberger et al., 2003; Lobo et al., 2003; Maier et al., 2003).

The major limitation in studies on the specificity and immunogenicity of EBA ligands is their expression and purification as soluble and properly folded recombinant proteins in sufficient amounts. Recombinant Region II (F1 and F2 domains) or F2 domain of EBA-175 ligand were obtained using bacterial (Pandley et al., 2002), insect (Liang et al., 2000; Ockenhouse et al., 2001) or yeast cells (Zhang \& Pan, 2005). Recombinant F2 domain of EBA-175 antigen expressed in E. coli was purified from inclusion bodies and renatured by oxidative refolding. In order to increase the level of EBA-175 F2 domain expression, sequences coding for the F2 domain, based on E. coli and Pichia codon usage, were designed (Yadava \& Ockenhouse, 2003). The protein expressed in P. pastoris was soluble and functional in comparison to the insoluble F2 domain produced in E. coli as inclusion bodies. Taking into account that EBA-175 Region II contains several cysteine-rich motifs, the eukaryotic yeast or baculovirus expression system seemed to be most suitable.

e-mail: jaskiew@iitd.pan.wroc.pl

*Preliminary report: an abstract on $22^{\text {nd }}$ IUMB\&37th FEBS Congress, 4-9 September, 2012 Seville, Spain.

Abbreviations: $\mathrm{EBA}$, erythrocyte binding antigen; $\mathrm{GdmCl}$, guanidine hydrochloride; GPA, glycophorin A; GPC, Glycophorin C; IPTG, isopropyl $\beta$-D-1-thiogalactopyranoside; MBP, maltose binding protein; RBC, red blood cells. 
Regarding expression of the EBA-140 ligand, only two reports are available to date. Similarly to EBA-175 antigen, EBA-140 binding Region II was obtained in the baculovirus expression system (Kobayashi et al., 2010) or bacterial expression system (Lin et al., 2012). Recombinant Region II and F1, F2 domains were also expressed separately on the surface of Chinese hamster ovary (CHO-K1) (Jiang et al., 2009), COS7 (Mayer et al., 2002) and HEK-293T cells (Lin et al., 2012).

It was shown that mouse and rabbit antibodies against the F2 domain of EBA-140 antigen inhibit the EBA140/GPC invasion pathway of human erythrocytes by P. falciparum (Narum et al., 2002; Maier et al., 2003). There is also one study on the naturally acquired antibody response to the EBA-140 ligand in populations of individuals living in endemic areas of Brazil (Ford et al., 2007). These modest data could suggest the potential importance of EBA-140 antigen as a novel vaccine candidate. This has encouraged us to obtain the recombinant EBA-140 ligand binding region in order to study its activity and immunogenicity. We have chosen the bacterial expression system as the most convenient and inexpensive method to obtain recombinant proteins in sufficient amounts. This report describes bacterial expression and purification of the truncated F2 domain of $P$. falciparum EBA-140 antigen. We have obtained pure and correctly folded functional recombinant protein; containing 197 of the 335 amino acid residues of the full-length F2 domain. This truncated form of EBA-140 F2 domain was shown to bind specifically to human erythrocytes but its binding was not as efficient as that of the whole Region II. This indicates that both DBL domains of EBA-140 antigen are required for effective binding to erythrocytes as shown in previous reports (Mayer et al., 2002; Lin et al., 2012).

\section{MATERIALS AND METHODS}

Bacterial strains and plasmids. E. coli XL1 Blue cells (Stratagene, La Jolla, CA, USA) for plasmid cloning and Rosetta-gami (Novagen-Merck, Darmstadt, Germany) for protein expression were used. Cloning vector pDrive (Qiagen, Hilden, Germany) and bacterial expression vector pMALc2x (New England BioLabs, Ipswich, MA, USA) were used.

Cloning of EBA-140 antigen Region II. Region II (amino acids 141-756) of the EBA-140 ligand (GenBank: AF 332918_1) was cloned from genomic DNA of P. falciparum clone Dd2 (ATCC, MR4, Manassas, VA, USA) with forward primer: CAA TAT ACG TTT ATA CAG AAA CGT ACT CAT TTG T'T'T GCT and reverse primer: TAT ATC GTG TTT TGT T'T'T AGG ATA TT'T A. Taq DNA Polymerase (Fermentas, Vilnius, Lithuania) was used in 35 cycles of amplification $\left(94^{\circ} \mathrm{C}\right.$, $\left.30 \mathrm{~s} ; 54^{\circ} \mathrm{C}, 30 \mathrm{~s} ; 72^{\circ} \mathrm{C}, 2 \mathrm{~min} 30 \mathrm{~s}\right)$ after a hot start at $94^{\circ} \mathrm{C}$ for $5 \mathrm{~min}$ and $10 \mathrm{~min}$ of final extension at $72^{\circ} \mathrm{C}$. The PCR product was purified using a gel extraction kit (Qiagen) and cloned into pDrive cloning vector (Qiagen) using T4 DNA ligase (Fermentas). The obtained pDriveRII recombinant plasmid was transformed into E. coli XL1 Blue competent cells and selected on LB-agar with $100 \mu \mathrm{g} / \mathrm{ml}$ ampicillin (Polfa Tarchomin, Warszawa, Poland). The sequence was confirmed by restriction fragment analysis and DNA sequencing.

Construction of pMalc2x-F2 expression vector. The recombinant plasmid pDrive-RII encoding Region II of the EBA-140 ligand was used as a template to amplify the F2 domain (amino acids 422-756) with Ac-
cuPrime Pfx SuperMix (Invitrogen, Carlsbad, CA, USA) in 35 cycles of amplification $\left(95^{\circ} \mathrm{C}, 15 \mathrm{~s} ; 54^{\circ} \mathrm{C}, 30 \mathrm{~s}\right.$; $68^{\circ} \mathrm{C}, 90 \mathrm{~s}$ ) after a hot start at $95^{\circ} \mathrm{C}$ for $5 \mathrm{~min}$ and 10 min of final extension at $68^{\circ} \mathrm{C}$. Forward primer: CGC GGG TCT AGA AGA TAT ACT GCT ACT ATT ATT AAA AGT introducing the $\mathrm{XbaI}$ restriction site and reverse primer: CGA TAT AAG CTT CTA ATG ATG ATG ATG ATG ATG CAG ATC CTC TTC TGA GAT GAG TTT TTG TTC TAT ATC GTG T'T'T TGT TT'T AGG introducing the Hind III restriction site and c-myc and 6xHis tags were used. The PCR product was purified using a PCR purification kit (Qiagen) and digested with restriction enzymes $\mathrm{XbaI}$ and HindIII (Fermentas). The digested and purified product was cloned into pMalc2x vector using T4 DNA ligase (Fermentas) transformed into E. coli XL1 Blue competent cells and selected on LB-agar with $100 \mu \mathrm{g} / \mathrm{ml}$ ampicillin. The pMalc2x-F2 plasmid was transformed into E. coli Rosetta-gami competent cells in order to express recombinant fusion protein.

Expression of MBP-F2 fusion protein in E. coli. Recombinant F2 domain of EBA-140 antigen was expressed in E. coli Rosetta-gami as the fusion protein with maltose binding protein (MBP) at the $\mathrm{N}$-terminal end and with c-myc and 6xHis tags at the C-terminus. A single bacterial colony containing pMalc $2 \mathrm{x}-\mathrm{F} 2$ vector encoding the MBP-F2 protein was inoculated into 10 $\mathrm{ml} \mathrm{LB}$ medium supplemented with $100 \mu \mathrm{g} / \mathrm{ml}$ ampicillin and $30 \mu \mathrm{g} / \mathrm{ml}$ chloramphenicol (Roth, Karlsruhe, Germany). After overnight cultivation $\left(30^{\circ} \mathrm{C}, 190 \mathrm{rpm}\right) 2 \mathrm{ml}$ aliquots were transferred into $200 \mathrm{ml}$ fresh LB medium containing $100 \mu \mathrm{g} / \mathrm{ml}$ ampicillin. The bacterial culture was continued $\left(30^{\circ} \mathrm{C}, 180 \mathrm{rpm}\right)$ until $\mathrm{OD}_{600 \mathrm{~nm}}$ reached 0.8 . To induce the MBP-F2 fusion protein expression, bacterial cells were cultured with $0.3 \mathrm{mM}$ isopropyl $\beta-\mathrm{D}-$ 1-thiogalactopyranoside (IPTG, Roth) at $30^{\circ} \mathrm{C}$ or $16^{\circ} \mathrm{C}$ for $20 \mathrm{~h}$. In order to assess the influence of cultivation time on protein expression level, small culture samples were taken 2, 4, 6, 14, 16, 18 and $20 \mathrm{~h}$ after induction and disintegrated by sonication. Protein content was evaluated by polyacrylamide gel electrophoresis (SDS/ PAGE). These initial studies indicated that optimal expression of the MBP-F2 fusion protein was achieved in E. coli Rosetta-gami cells cultivated with $0.3 \mathrm{mM}$ IPTG at $30^{\circ} \mathrm{C}$ for $4 \mathrm{~h}$. Large-scale expression of the MBP-F2 fusion protein was performed in 3 liter culture of E. coli Rosetta-gami in conditions described above. The bacteria were then harvested by centrifugation at $6000 \mathrm{rpm}$ at $4^{\circ} \mathrm{C}$ and stored at $-20^{\circ} \mathrm{C}$.

Purification of MBP-F2 fusion protein. The E. coli cells harvested by centrifugation were resuspended in pre-cooled column buffer $(50 \mathrm{mM}$ Tris/HCl, 300 $\mathrm{mM} \mathrm{NaCl}, \mathrm{pH}$ 7.5) containing $1 \mathrm{mM}$ EDTA, $5 \mathrm{mM}$ $\beta$-mercaptoethanol, $1 \mathrm{mM}$ PMSF and protease inhibitor cocktail $(10 \mu \mathrm{l}$ per $1 \mathrm{ml}$ of buffer, Sigma-Aldrich, St. Louis, MO, USA). The suspension was frozen in dry iceethanol bath, stored overnight at $-20^{\circ} \mathrm{C}$ and then thawed in cold water. The cells in the suspension were lysed by sonication and centrifuged at $14000 \mathrm{rpm}$ for $30 \mathrm{~min}$ at $4^{\circ} \mathrm{C}$. The supernatant was added to $10 \mathrm{ml}$ of nickel nitrilotriacetic acid resin (Ni-NTA, Qiagen) equilibrated with the column buffer and then the whole suspension was mixed for $3 \mathrm{~h}$ at $4^{\circ} \mathrm{C}$. The resin was loaded onto a $50 \mathrm{ml}$ column washed with 21 of the column buffer. To remove nonspecifically binding proteins $20 \mathrm{ml}$ of the column buffer containing $20 \mathrm{mM}$ imidazole was used. The bound proteins were subsequently eluted with the column buffer containing imidazole at the following concentrations: $50 \mathrm{mM}, 150 \mathrm{mM}$ and $200 \mathrm{mM}$. Fractions 
were analyzed by SDS/PAGE and Western blotting. Fractions eluted with $200 \mathrm{mM}$ imidazole containing the MBP-F2 fusion protein and truncated F2 domain were collected.

Proteins were separated by SDS/PAGE according to the method of Laemmli (Laemmli, 1970) using 10\% gel and visualized with Coomassie Brilliant Blue R-250 (CBB, Merck). The PageRuler Prestained Protein Ladder (Fermentas) was used as protein standards.

Western blotting. Proteins fractionated by SDSPAGE were transferred to nitrocellulose membrane (Schleicher \& Schuel, Dassel, Germany) according to the method of Towbin (Towbin et al., 1979) and detected with mouse monoclonal antibodies (MoAb) directed against c-myc epitope (9E10, ATCC) and histidine-tag (His-1, Sigma-Aldrich).

Analytical size-exclusion chromatography. Fractions containing the MBP-F2 protein and truncated F2 domain, eluted with $200 \mathrm{mM}$ imidazole, were pooled and concentrated ten times using a $10000 M_{\mathrm{r}}$ cut-off Amicon Ultra device (Millipore, Billerica, MA, USA). A sample containing about $750 \mu \mathrm{g}$ of total protein was analyzed on an analytical 10/300 GL Superdex 200 column (AKTA Purifier, GE Healthcare, Uppsala, Sweden) in the column buffer. Protein content was evaluated spectrophotometrically at $280 \mathrm{~nm}$. In order to optimize separation of high molecular mass aggregates containing the MBP-F2 fusion protein and truncated F2 domain, samples were analyzed in the column buffer containing different concentrations of DTT $(5-25 \mathrm{mM})$ and guanidinium chloride (0.2-0.75 M, GdmCl).

Analytical size-exclusion chromatography used for evaluation of the purified, truncated F2 domain (250 $\mu \mathrm{g})$ was performed on a 10/300 GL Superdex $200 \mathrm{col}-$ umn equilibrated with the column buffer containing $10 \%$ glycerin at a flow rate of $0.4 \mathrm{ml} / \mathrm{min}$ at room temperature (RT). Protein molecular weight standards used were: $66.4 \mathrm{kDa}$ albumin, $43 \mathrm{kDa}$ ovalbumin, $25 \mathrm{kDa}$ chymotrypsinogen A, $14.4 \mathrm{kDa}$ cytochrome c (Sigma-Aldrich).

Preparative size-exclusion chromatography of truncated F2 domain. The concentrated sample containing about $7 \mathrm{mg}$ of total protein was mixed in volume ratio $1: 2$ with the column buffer containing $0.2 \mathrm{M}$ $\mathrm{GdmCl}$ and $10 \mathrm{mM}$ DTT, incubated for $1 \mathrm{~h}$ at $25^{\circ} \mathrm{C}$ and loaded onto a preparative Hiload 26/60 Superdex 200 size-exclusion column (AKTA Purifier), previously equilibrated with the column buffer, and eluted at a flow rate of $1 \mathrm{ml} / \mathrm{min}$ at $\mathrm{RT}$. The eluted fractions were analyzed by SDS/PAGE. Fractions containing the purified, truncated F2 domain were pooled and concentrated using a $10000 M_{\mathrm{r}}$ cut-off Amicon Ultra device to $0.5 \mathrm{mg} /$ $\mathrm{ml}$ of protein and then dialyzed at $4^{\circ} \mathrm{C}$ for $20 \mathrm{~h}$ in the three following steps: against $50 \%, 20 \%$ and finally $10 \%$ glycerin in the column buffer. Protein concentration was determined spectrophotometrically at $280 \mathrm{~nm}$ by the Bradford method (Bradford, 1976) using a Nanoquant protein assay reagent (Roth).

Circular dichroism of purified, truncated F2 domain. The folding state of the purified, truncated F2 domain (at $2 \mu \mathrm{M}$ concentration) and of the whole baculovirus-expressed Region II of EBA-140 antigen (GenScript, Hong Kong) were evaluated by circular dichroism (CD) spectroscopy. CD spectra were recorded on a Jasco J-600 spectropolarimeter (Jasco Inc., Easton, MD, USA)), at RT. Path length of $1 \mathrm{~mm}$ was used. Each spectrum represents the average of four scans. The data are presented as mean residue molar ellipticity [ $\theta \mathrm{r}]$.

Mass spectrometry. Molecular weight of the truncated F2 domain was confirmed by MALDI-TOF MS (matrix-assisted laser desorption/ionization-time of flight mass spectrometry) using an Autoflex III mass spectrometer (Bruker Daltonics, Hamburg, Germany). $10 \mu \mathrm{l}$ of protein sample $(0.5 \mathrm{mg} / \mathrm{ml})$ in $50 \mathrm{mM}$ Tris $/ \mathrm{HCl}, 300$ $\mathrm{mM} \mathrm{NaCl}, 10 \%$ glycerin were desalted using reversedphase zip-tips C-18 (Millipore) according to the manufacturer's recommendations. The bound protein was eluted with $2 \mu \mathrm{l}$ of $0.05 \%$ trifluoroacetic acid in $50 \%$ acetonitrile. The obtained sample was mixed with a matrix solution. The mixtures of protein sample and matrix solution were loaded onto the MALDI target and dried. The mass spectra were scanned in the range of $8000+$ $70000 \mathrm{~m} /$ q. The external calibration was carried out using Protein Standard II (Bruker Daltonics): trypsinogen, protein $\mathrm{A}$, and bovine albumin.

Determination of three $\mathrm{N}$-terminal amino acids of the truncated F2 domain fragment was carried out by Edman degradation by BioCentrum (Krakow, Poland).

Flow cytometry analysis. $50 \mu$ l of the truncated F2 domain $(0.5 \mathrm{mg} / \mathrm{ml})$ or of the whole Region II $(0.15$ $\mathrm{mg} / \mathrm{ml}$ ) - were incubated with $3 \times 10^{5}$ native human red blood cells (RBC) treated with trypsin (Sigma-Aldrich) or neuraminidase (Vibrio cholerae, Serva, Heidelberg, Ger-

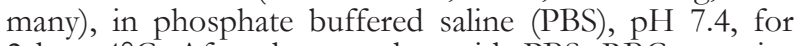
$2 \mathrm{~h}$ at $4^{\circ} \mathrm{C}$. After three washes with PBS, RBC were incubated for $1 \mathrm{~h}$ at $4^{\circ} \mathrm{C}$ with rabbit serum (diluted 1:200) raised against the whole Region II. Then, after 3 washes with PBS, RBC were incubated for $30 \mathrm{~min}$ at $4^{\circ} \mathrm{C}$ with FITC-conjugated swine anti-rabbit Ig antibody (DakoCytomation, Glostrup, Denmark). Erythrocytes were analyzed for fluorescence intensity using flow cytometry (FACSCalibur, BD Biosciences, San Jose, Ca, USA).

Immunization of rabbits. Rabbits were immunized with $50 \mu \mathrm{g}$ of baculovirus-expressed Region II (GenScript) in MPL adjuvant (Baldridge \& Crane, 1999) and boosted in three-week intervals with $50 \mu \mathrm{g}$ of the antigen. One rabbit was immunized with MPL adjuvant alone to provide control serum. Sera were collected 14 days after the fourth immunization and used for assays.

\section{RESULTS AND DISCUSSION}

\section{Expression of $\mathrm{F} 2$ domain of EBA-140 antigen}

Recombinant F2 domain was expressed in E. coli Rosetta-gami cytoplasm as a fusion protein with MBP. It is known that MBP can promote proper folding of fusion proteins and thus increase their solubility. It was frequently observed that MBP fusion proteins could be efficiently overexpressed and exhibited enhanced solubility and stability compared to their untagged counterparts (Kapust \& Waugh, 1999). E. coli Rosetta-gami is a trxB mutant, which facilitates cytoplasmic disulfide bond formation (Stewart et al., 1998) and can be particularly useful for the folding of proteins containing several disulphide bridges, like the F2 domain of $P$. falciparum EBA140 antigen.

In order to obtain soluble recombinant F2 domain of the EBA-140 ligand in a sufficient amount, pilot experiments were performed to determine optimal cultivation conditions, including appropriate growth temperature and time of harvest after induction. Initial studies suggested that optimal expression of MBP-F2 fusion protein was achieved in E. coli Rosetta-gami cells induced with $0.3 \mathrm{mM}$ IPTG and cultivated at $30^{\circ} \mathrm{C}$ for $4 \mathrm{~h}$ or at $16^{\circ} \mathrm{C}$ for $14 \mathrm{~h}$ (Fig. 1). However, the recombinant MBPF2 fusion protein was shown to be rapidly degraded: in addition to the MBP-F2 protein $(\sim 85 \mathrm{kDa})$, a shorter 


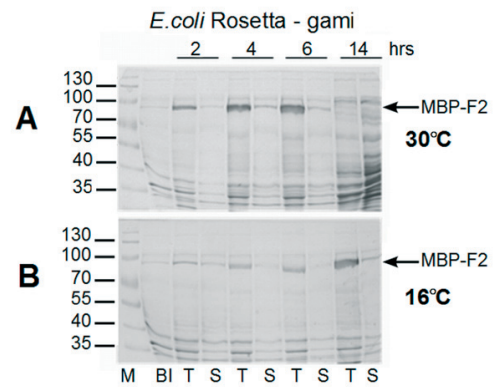

Figure 1. Optimization of MBP-F2 fusion protein expression in E. coli strain Rosetta-gami at $30^{\circ} \mathrm{C}(\mathrm{A})$ and $16^{\circ} \mathrm{C}(\mathrm{B})$ and various cultivation times after $0.3 \mathrm{mM}$ IPTG induction.

SDS/PAGE of bacterial proteins in $10 \%$ gel stained with CBB; T, total extract; $\mathrm{S}$, soluble fraction; $\mathrm{BI}$, total extract before expression induction; M, protein molecular weight standards.

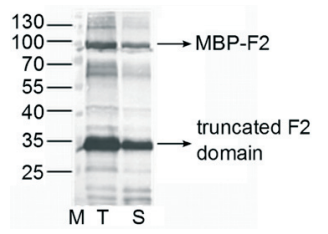

Figure 2. Spontaneous degradation of MBP-F2 fusion protein in the cytoplasm of $E$. coli Rosetta-gami cells.

Western blotting with anti-myc MoAb; T, total extract; $S$, soluble fraction; $M$, protein molecular weight standards; MBP-F2 fusion protein ( $85 \mathrm{kDa})$; truncated F2 domain ( $30 \mathrm{kDa})$.

protein: truncated F2 domain (F2 domain fragment, 30 $\mathrm{kDa}$ ) was present in cell lysate (Fig. 2). Modifications of growth conditions did not significantly reduce this degradation. These results suggest that the recombinant MBPF2 fusion protein may be susceptible to spontaneous degradation in the cytoplasm of $E$. coli cells. The large scale expression of the MBP-F2 fusion protein was performed in Rosetta-gami 31 bacterial culture transformed with pMALc2x-F2 expression vector, induced with 0.3 $\mathrm{mM}$ IPTG and cultured at $30^{\circ} \mathrm{C}$ for $4 \mathrm{~h}$.

\section{Purification of EBA-140 truncated F2 domain}

MBP-F2 fusion protein expressed in the conditions described above was purified by affinity chromatography on Ni-NTA resin. Fractions eluted with $200 \mathrm{mM}$ imidazole containing the MBP-F2 fusion protein and truncated F2 domain (Fig. 3) were pooled, concentrated and analyzed on an analytical 10/300 GL Superdex 200 column (Fig. 4).

It was observed that the MBP-F2 fusion protein forms aggregates with the truncated F2 domain (Fig. 4A). The aggregates are probably formed during MBP-F2 expression in E. coli cells and dissociate under reducing and denaturing conditions of SDS/PAGE. It has been shown previously that aggregation of recombinant proteins can

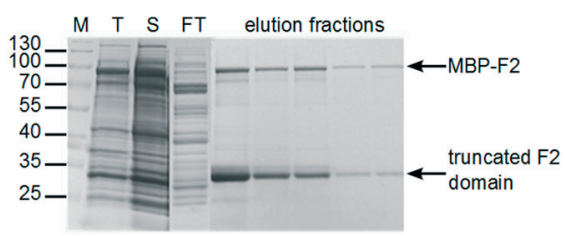

Figure 3. Affinity purification of EBA-140 truncated F2 domain on Ni-NTA resin.

SDS/PAGE of proteins in 10\% gel stained with CBB; T, total extract; $\mathrm{S}$, soluble fraction; FT, flow-through of Ni-NTA resin; $M$, protein molecular weight standards; MBP-F2 fusion protein ( $85 \mathrm{kDa})$; truncated F2 domain $(\sim 30 \mathrm{kDa})$.
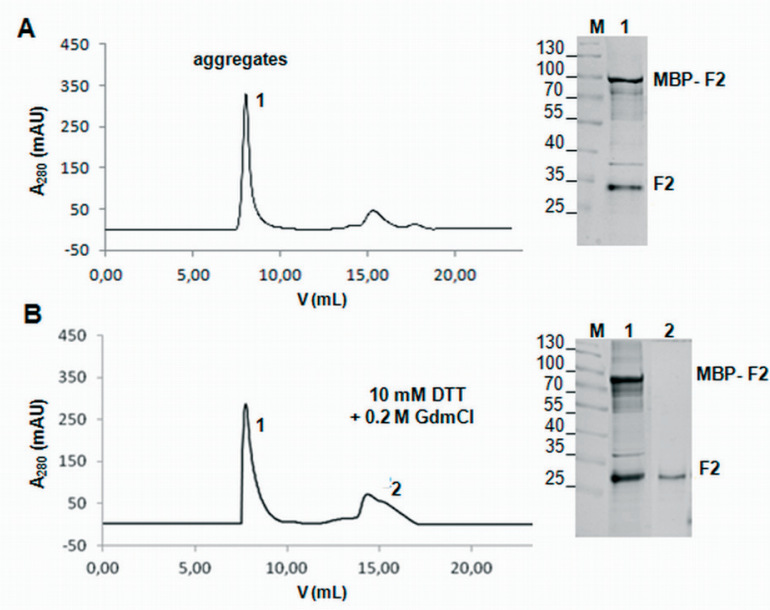

Figure 4. Analytical size-exclusion chromatography on a Superdex 200 column of affinity purified EBA-140 truncated F2 domain.

Chromatogram A (run in column buffer), peak 1 and SDS/PAGE lane 1, aggregates of MBP-F2 fusion protein with F2 domain fragment; Chromatogram B (run in column buffer containing $10 \mathrm{mM}$ DTT and $0.2 \mathrm{M} \mathrm{GdmCl}$ ), peak 1 and SDS/PAGE lane 1, aggregates of MBP-F2 fusion protein with the truncated F2 domain, peak 2 and lane 2, the truncated F2 domain; M, protein molecular weight standards.

occur during overexpression in bacterial cells because of high protein concentration (Villaverde \& Carrió, 2003). Aggregation of a protein fused to MBP was also shown for $\mathrm{N}$-terminal domains of the carcinoembryonic antigen (Czepczyńska-Krężel et al., 2011). In the case of EBA140 Region II (F1 and F2 domains) one of the causes of aggregation may be its natural ability to form dimers. It was shown before that recombinant EBA-175 homologous Region II exists in both monomeric and dimeric forms (Tolia et al., 2005). The structures of EBA175 antigen and its parologue EBA-140 are similar and therefore we speculate that the F2 domain of EBA-140 antigen may also be involved in domain to domain interaction.

Since the degradation product of the F2 domain accounted approximately for $50 \%$ of the obtained protein, we decided to purify this fragment. Therefore, it was necessary to find the optimal conditions for disrupting aggregates of the truncated F2 domain with the MBP-
A

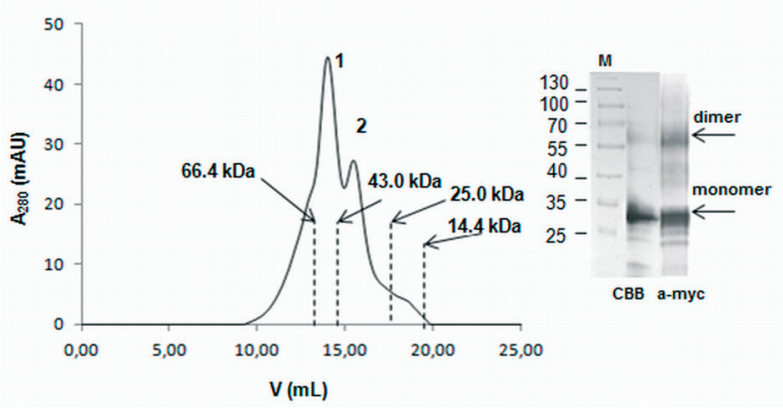

Figure 5. Analytical size exclusion chromatography on a Superdex 200 column of the pure EBA-140 truncated $F 2$ domain (A). Purified protein was analyzed by SDS/PAGE in 10\% gel stained with $\mathrm{CBB}$ and Western blotting with anti-myc MoAb (B); peak 1 corresponds to the dimer form of the truncated F2 domain and peak 2 corresponds to the monomer form of the truncated F2 domain; $\mathrm{M}$, protein molecular weight standards; Elution volumes of standards used in column calibration are marked by dashed lines. 


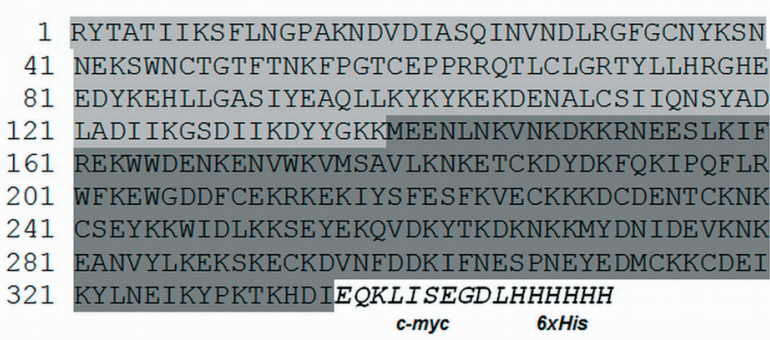

Figure 6. The amino acid sequence of cloned $P$. falciparum EBA140 antigen F2 domain (335 aa res.) with c-myc and 6xHis tags. The sequence of purified, truncated F2 domain (197 aa res.) is shaded in dark gray.

F2 fusion protein. Several reducing agents, $\mathrm{pH}$ values and chaotropic salts were tested and the dissociation of aggregates was monitored using the analytical Superdex 200 column. It was found that DT'T at concentrations of $5-25 \mathrm{mM}$ or $\mathrm{GdmCl}$ at concentrations of $0.2-0.75$ M caused partial separation of the aggregates (data not shown). The best conditions for separation of the truncated F2 domain from aggregates were found to be 0.2 $\mathrm{M} \mathrm{GdmCl}$ and $10 \mathrm{mM}$ DT'T used as components of the column buffer (Fig. 4B). However, we were unable to obtain complete disruption of the aggregates.

Purification of the truncated F2 domain was performed on the preparative Superdex 200 column in the conditions described in the Materials and Methods. It was noticed that $10-50 \%$ concentration of glycerin in the column buffer during dialysis of eluted fractions suppressed aggregate formation and increased solubility of the recombinant protein. The final yield of the truncated F2 domain was about $1.0 \mathrm{mg}$ per liter of bacterial culture. The purified protein was stored in $50 \mathrm{mM}$ Tris/ $\mathrm{HCl}, 300 \mathrm{mM} \mathrm{NaCl}, 10 \%$ glycerin, $\mathrm{pH}$ 7.5.

Homogeneity of the purified, truncated F2 domain was confirmed by analytical size-exclusion chromatography (Fig. 5A). The Superdex 200 elution profile indicated two peaks: the first corresponding to the truncated F2 domain dimer (52.6 kDa, elution volume 14 $\mathrm{ml}$ ) and the second one corresponding to the monomer of truncated F2 domain (26.3 kDa, elution volume 15.5 $\mathrm{ml})$. This suggests that the truncated F2 domain may exist in solution in both monomer and dimer forms. Indeed, it was shown by SDS-PAGE and Western blotting that the truncated F2 domain migrated as a monomer $(\sim 26 \mathrm{kDa})$ and as a band corresponding to the dimer
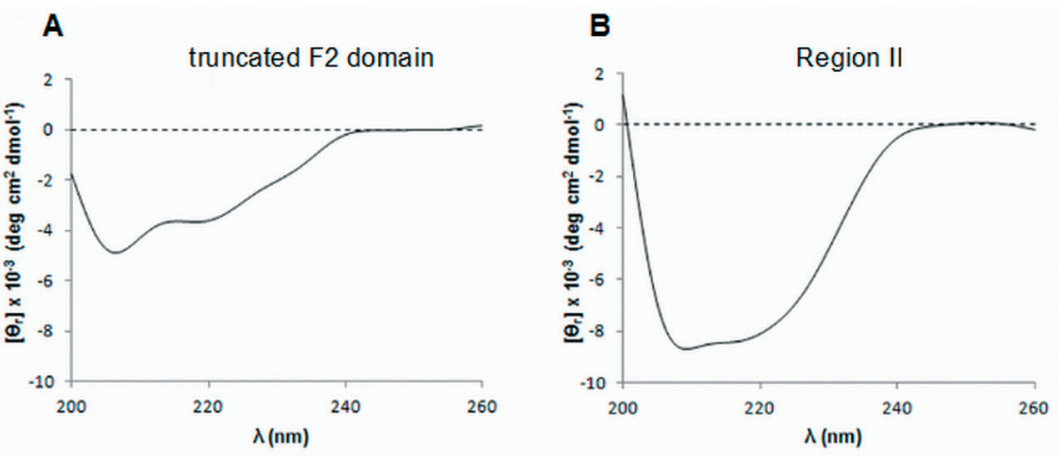

Figure 7. Circular dichroism spectra (195-270 nm) of EBA-140 truncated F2 domain (A) and whole Region II (B);

solutions of the truncated F2 domain $(2 \mu \mathrm{M})$ and Region II $(0.5 \mu \mathrm{M})$ in $50 \mathrm{mM}$ Tris/ $\mathrm{HCl}, 300$ $\mathrm{mM} \mathrm{NaCl}, 10 \%$ glycerin, $\mathrm{pH} 7.5$ were used. form $(\sim 52 \mathrm{kDa})$ (Fig. 5B). The dimerization is probably caused by hydrophobic interaction and salt bridges, as it was shown for Region II of P. falciparum EBA-175 ligand (Tolia et al., 2005). The obtained truncated, recombinant F2 domain of EBA-140 antigen was more than 95\% pure.

\section{Molecular mass analysis of truncated F2 domain}

Sequencing of the purified, truncated F2 domain identified its consensus $\mathrm{N}$-terminal amino acid sequence (Met-Glu-Glu) and revealed a proteolytic cleavage site within EBA-140 F2 domain (Fig. 6). It allows to identify and calculate the mass of the 213 amino acid protein consisting of 197 aa residues of the F2 domain and tags (16 aa). The molecular mass of the truncated F2 domain, evaluated by mass spectrometry was $26300 \mathrm{Da}$ and it corresponded exactly to the molecular mass calculated according to the amino acid sequence.

\section{Conformation analysis of truncated F2 domain}

Proper folding of the recombinant EBA-140 truncated F2 domain was confirmed by circular dichroism. The CD spectrum of the purified, truncated F2 domain showed minima near 208 and $220 \mathrm{~nm}$, similarly to the recombinant Region II of the EBA-140 ligand obtained in the baculoviral system (Fig. 7). These results indicate the presence of a significant $\alpha$-helical content in the EBA-140 truncated F2 domain.

\section{Functional analysis of EBA-140 truncated F2 domain}

The ability of the truncated F2 domain to bind its ligand was evaluated by examining its interaction with native and neuraminidase or trypsin treated RBC in flow cytometry (Fig. 8). Binding of the truncated F2 domain was compared to that of baculovirus-expressed Region II of EBA-140 antigen. It was shown that the truncated F2 domain could bind to native human erythrocytes, but did not bind to neuraminidase- or trypsin-treated RBC, similarly to the whole recombinant Region II. These results indicated that the recombinant, truncated F2 domain, although comprising only 197 of the 335 amino acid residues of the $\mathrm{F} 2$ domain, was still functional and could bind specifically to human erythrocytes in a sialic acid dependent manner. However, binding of the truncated F2 domain to RBC evaluated by flow cytometry was much weaker than binding of the full-length Region II of EBA-140 antigen, even at high concentration.

It was shown that the recombinant Region II of $P$. falciparum EBA-140 antigen expressed on the surface of $\mathrm{CHO}$ $\mathrm{K} 1$ cells bound to native but not to neuraminidase-treated erythrocytes (Jiang et al., 2009). Similar results were obtained previously for the whole EBA-140 Region II expressed on the surface of COS7 cells (Mayer et al., 2002). Moreover, it was also observed that the F1 and F2 domains of EBA140 Region II expressed separately on the surface of COS7 cells did not bind to human erythrocytes, which may suggest that both domains are simultaneously required for binding (Mayer et al., 2002). This observation was recently confirmed and demonstrated for F1 

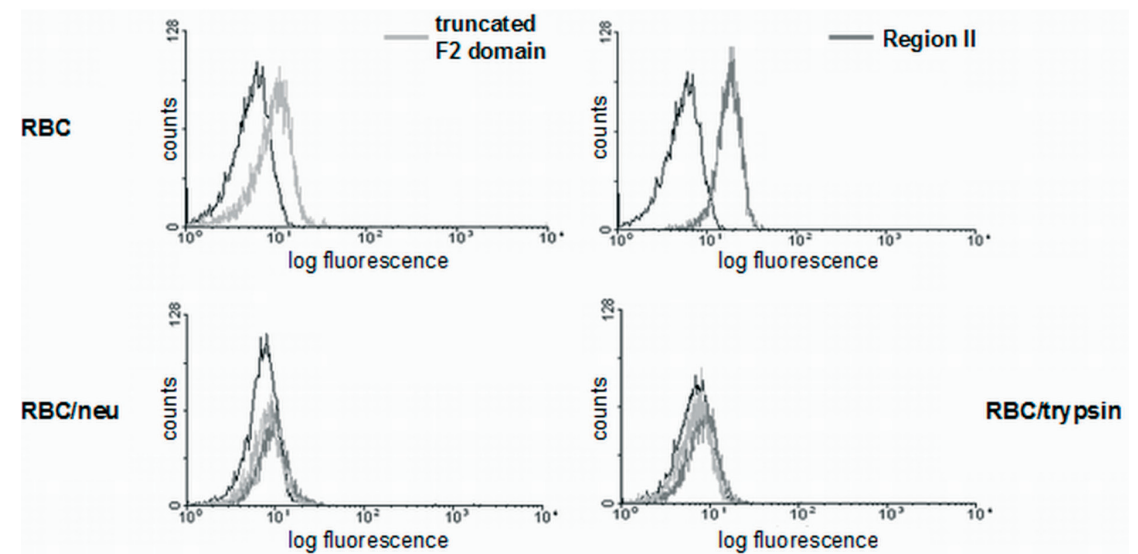

Figure 8. Flow cytometry analysis of the truncated F2 domain and full length Region II binding to native $(\mathrm{RBC})$ and neuraminidase ( $\mathrm{RBC} / \mathrm{neu}$ ) or trypsin ( $\mathrm{RBC} /$ trypsin) treated human erythrocytes.

Black line corresponds to control (erythrocytes incubated with anti-Region II rabbit serum); light grey line corresponds to the truncated F2 domain; dark grey line corresponds to Region II of EBA-140 antigen.

and F2 domains expressed individually on HEK-293T cells and tested for erythrocyte binding (Lin et al., 2012). In contradiction to EBA-140 antigen, it was shown that the recombinant Region II and F2 domain (but not F1 domain) of EBA-175 homologous antigen bound human erythrocytes in a similar manner (Liang et al., 2000; Ockenhouse et al., 2001; Pandley et al., 2002). These data suggest that the most important region required by EBA-175 antigen to bind to its GPA ligand is the F2 domain.

Our findings have demonstrated that the truncated F2 domain of EBA-140 antigen can still specifically bind to erythrocytes, although its binding is not as efficient as binding of the whole Region II. This confirms that both $\mathrm{F} 1$ and $\mathrm{F} 2$ domains of EBA-140 antigen are required for effective erythrocyte binding as shown previously (Mayer et al., 2002; Lin et al., 2012). However, in comparison with the total loss of activity shown for the EBA-140 F2 domain expressed as surface recombinant protein and examined for erythrocyte binding by rosetting assay, the soluble, recombinant and truncated F2 domain can still bind to erythrocytes, as confirmed by flow cytometry. The observed discrepancies between the results can be explained by the sensitivity of methods employed.

\section{CONCLUSIONS}

The EBA-140 ligand is a member of the $P$. falciparum EBL family of proteins responsible for human erythrocyte binding. This paper describes bacterial expression and purification of the recombinant, truncated F2 domain of the $P$. falciparum EBA-140 ligand. Two major conclusions can be drawn from this study.

The first conclusion is that the soluble, pure and properly folded truncated F2 domain (197 aa res.) of EBA-140 antigen could be obtained in milligram quantities in bacteria.

The second and most important conclusion is that the truncated F2 domain obtained by this method is functional and can bind to human erythrocytes, although its binding is not as efficient as that of the full-length Region II (F1 and F2 domains) of EBA-140 antigen. It is consistent with the notion that both F1 and F2 domains of EBA-140 antigen are required for effective erythrocyte binding.

\section{Acknowledgemets}

The research was supported by grant No N N302 281436 from the Ministry of Science and Higher Education of Poland.

\section{REFERENCES}

Adams JH, Blair PL, Kaneko O, Peterson DS (2001) An expanding ebl family of Plasmodium falciparum. Trends Parasitol 17: 297-299.

Baldridge JR, Crane RT (1999) Monophosphoryl lipid A (MPL) formulations for next generation of vaccines. Methods 19: 103-107.

Bradford MM (1976) A rapid and sensitive method for the quantitation of microgram quantities of protein utilizing the principle of protein-dye binding. Anal Biochem 72: 248-254.

Cowman AF, Crabb BS (2006) Invasion of red blood cells by malaria parasites. Cell 124: 755-766.

Czepczyńska-Krężel H, Czerwinski M, Krężel A, Krop-Watorek A (2011) Isolation of carcinoembryonic antigen N-terminal domains (N-A1) from soluble aggregates. Protein Expr Purif 78: 78-85.

Ford L, Lobo CA, Rodrigues M, Zalis MG, Machado RLD, Rossit ARB, Cavasini CE, Couto AAR, Enyong PA, Lustigman S (2007) Differential antibody responses to Plasmodium falciparum invasion ligand proteins in individuals living in malaria-endemic areas in Brasil and Camerun. Am J Trop Med Hyg 77: 977-983.

Gaur D, Mayer DCG., Miller LH, Parasite ligand-host receptor interactions during invasion of erythrocytes by Plasmodium merozoites. (2004) Int J Parazytol 34: 1413-1429.

Gilberger TW, Thompson JK, Triglia T, Good RT, Duraisingh MT, Cowman AF (2003) A novel erythrocyte binding antigen-175 paralogue from Plasmodium falciparum defines a new trypsin-resistant receptor on human erythrocytes. I Biol Chem 278: 14480-14486.

Greenwood BM, Fidock DA, Kyle DE, Kappe SHI., Alonso PL, Collins FH, Duffy PE, (2008) Malaria: progress, Perils and prospects for eradication. I Clin Invest 118: 1266-1276.

Jaśkiewicz E (1991) Molekularne i genetyczne podstawy układu grupowego Gerbich ludzkich erytrocytów. Post Biochem 37: 75-81.

Jaśkiewicz E, Jedynak A, Zioło E (2005) Expression of recombinant forms of human $21.5 \mathrm{kDa}$ myelin basic protein and proteolipid protein in CHO cells. Acta Biochim Pol 52: 863-866.

Jaśkiewicz E (2007) Glikoforyny ludzkich erytrocytów jako receptory dla zarodźca sierpowego malarii Plasmodium falciparum. Postepy Hig Med Dośw 61: 718-724 (in Polish).

Jaśkiewicz E, Graczyk J, Rydzak J (2010) Białka biorące udział w procesie inwazji erytrocytów ludzkich przez zarodźce malarii. Postępy Hig Med Dośw 64: 617-626 (in Polish).

Jiang L, Duriseti S, Sun P, Miller LH (2009) Molecular basis of binding of the Plasmodium falciparum receptor BAEBL to erythrocyte receptor glycophorin C. Mol Biochem Parasitol 168: 49-54.

Kapust RB, Waugh DS (1999) Escherichia coli maltose-binding protein is uncommonly effective at promoting the solubility of polypeptides to which it is fused. Protein Sci 8: 1668-1674.

Kobayashi K, Kato K, Sugi T, Takemae H, Pandey K, Gong K, Tohya Y, Akashi H (2010) Plasmodium falciparum BAEBL binds to heparan sulfate proteoglycans on the human erythrocyte surface. J Biol Chem 285: $1716-1725$.

Laemmli UK (1970) Cleavage of structural proteins during the assembly of the head of bacteriophage T4. Nature 227: 680-685.

Lin DH, Malpede BM, Batchelor JD, Tolia NH (2012) Crystal and solution structures of Plasmodium falciparum Erythrocyte Binding Antigen 140 reveal determinants of receptor specificity during erythrocyte invasion. J Biol Chem 287: 36830-3686.

Liang H, Narum DL, Fuhrmann SR, Luu T, Sim BKL (2000) A recombinant baculovirus-expressed Plasmodium falciparum receptorbinding domain of erythrocyte binding protein EBA-175 biologically mimics native protein. Infect Immunity 68: 3564-3568.

Lobo CA, Rodriguez M, Reid M, Lustigman S (2003) Glycophorin C is the receptor for the Plasmodium falciparum erythrocyte binding ligand PfEBP-2 (baebl). Blood 101: 4628-4631.

Maier AG, Duraisingh MT, Reeder JC, Patel SS, Kazura JW, Zimmerman PA, Cowman AF (2003) Plasmodium falciparum erythrocyte inva- 
sion through glycophorin $\mathrm{C}$ and selection for Gerbich negativity in human populations. Nat Med 9: 87-92.

Mayer DC, Mu JB, Feng X, Su XZ, Miller LH (2002) Polymorphism in a Plasmodium falciparum erythrocyte-binding ligand changes its receptor specificity. J Exp Med 196: 1523-1528.

Narum DL, Fuhrmann SR, Luu T, Sim BK (2002) A novel Plasmodium falciparum erythrocyte binding protein (EBP2/BAEBL) involved in erythrocyte receptor binding. Mol Biochem Parasitol 119: 159-168.

Ockenhouse CF, Barbosa A, Blackhall DP, Murphy CI, Kashala O, Dutta S, Lanar DE, Daugherty JR (2001) Sialic acid dependent binding of baculovirus-expessed recombinant antigens from Plasmodium falciparum EBA-175 to glycophorin A. Mol Biochem Parasitol 113: 9-21.

Pandley KC, Singh S, Pattnaik P, Pillai CR, Lynn A, Chitnis CE (2002) Bacterially expressed and refolded receptor binding domain of Plasmodium falciparum EBA-175 elicits invasion inhibitory antibodies. Mol Biochem Parasitol 123: 23-33.

Pierce SK, Miller LH (2009) World Malaria Day 2009: what Malaria knows about the immune system that immunologists still do not. $J$ Immunol 182: 5171-5177.

Sim BK, Chitnis CE, Wasniowska K, Hadley TJ, Miller LH (1994) Receptor and ligand domains for invasion of erythrocytes by Plasmodium falciparu. Science 264: 1941-1944.
Stewart EJ, Aslund F, Beckwith J (1998) Disulfide bond formation in the Escherichia coli cytoplasm: an in vivo role reversal for the thioredoxins. EMBO J 17: 5543-5550.

Thompson JK, Triglia T, Reed MB, Cowman AF (2001) A novel ligand from Plasmodium falciparum that binds to a sialic acid-containing receptor on the surface of human erythrocytes. Mol Microbiol 41: 47-58.

Tolia NH, Enemark EJ, Sim BKL, Joshua-Tor L (2005) Structural basis for the EBA-175 erythrocyte invasion pathway of the malaria parasite Plasmodium falciparum. Cell 122: 183-193.

Towbin H, Staehelin T, Gordon J (1979) Electrophoretic transferof proteins from polyacrylamide gels to nitrocellulose sheets: procedure and some applications. Proc Natl Acad Sci USA 76: 4350-4354.

Villaverde A, Carrió MM (2003) Protein aggregation in recombinant bacteria: biological role of inclusion bodies. Biotechnol Lett 25: 13851395.

Yadava A, Ockenhouse CF (2003) Effect of codon optimization on expression levels of a functionally folded malaria vaccine candidate in prokaryotic and eukaryotic expression systems. Infect Immun 71: 4961-4969.

Zhang D, Pan W (2005) Evaluation of three Pichia pastoris-expressed Plasmodium falciparum merozoite proteins as a combination vaccine against infection with blood stage parasites. Infec Immunity 73: 65306536. 